\title{
Protein Transport Across Pulmonary Alveolar Epithelium
}

\author{
Kwang-Jin Kim, Ph.D. \\ Assistant Professor of Medicine and Physiology \\ Departmet of Medicine and Physiology, Cornell University Medical College, \\ 1300 York Avenue, New York, NY 10021
}

The distal airways of the lung terminate in alveolar air sacs which must be kept relatively fluid-free for efficient gas exchange. Fluid balance in the alveoli can be altered due to injury to the alveolarcapillary barrier and/or by other cardiopulmonary complications (e.g., congestive heart failure). It has become appreciated recently that component of the alveolar-capillary barrier for regulation of alveolar epithelium is probable the single most important of the alveolar-capillary barrier for regulation of alveolar fluid and solute content, and for the prevention and resolution of alveolar pulmonary edema.

Until recently, the majority of investigations of alveolar fluid balance and solute (e.g., ions and nonelectrolytes) transport relied on intact lung models. The information obtained from these intact mammalian lung studies in vivo and in vitro, while useful, can be difficult to interpret mechanically, due largely to the anatomical complexity of the lung. In order to obtain more precise information about alveolar epithelial properties, studies of isolated preparations have provided useful additional approaches to the underlying transport mechanisms and pathways in the alveolar capillary wall. The barrier functions of the alveolar epithelium are therefore being studied in a number of ways, in addition to intact lung investigations, including monolayers of alveolar epithelial cell cultures as an in vitro model of alveolar epithelium and anatomically simpler amphibian lungs representing an intact preparation of alveolar epithelium. In this review, the bar- rier properties of the alveolar epithelium relevant to alveolar protein transport and fluid balance, citing the pertinent supporting experimental data where appropriate, will be discussed.

Macromolecules in general are thought to traverse biological tissue barriers by pathways probable different from those used by small molecules (e. g., ions and sugars). Macromolecules are also not thought to be actively transported, It has recently become appreciated that macromolecule transport probably involves vesicular uptake and secretion pathways with or without modification of the molecules within the cells (e.g., via lysosomal processing of the proteins into amino acids.). There are experimental models for each of these two patterns of epithelial macromolecule transport ${ }^{1,2}$.

Protein transport across the air-blood barrier in the lung may be of considerable importance, in that serum proteins (e.g., albumin) may be involved in the pathogenesis and resolution of alveolar pulmonary edema. Clearance of these proteins from the alveolar air spaces may become a formidable task for a damaged air-blood barrier. Even in normal lungs, it is now generally understood that alveolar fluid contains small concentrations of antioxidant proteins and immunoglobulins, which may be important for lung defenses. Unfortunately, little is known about the pathways and underlying mechanisms of macromolecule transport across alveolar epithelium.

Historically, it has even been controversial wheth- 
ere macromolecules such as serum proteins are able to traverse the air-blood barrier at all. As early as 1936, Fox ${ }^{3)}$ utilized intact rabbit and dog lungs to show that intratracheally-instilled anti-sera largely remained in thd air spaces for up to 48 hours. Thus, the air-blood barrier was thought to severely restrict the passage of the proteins studied. Drinker et $\mathrm{al}^{4)}$ instilled serum protein (e.g., hemoglobin, albumin) tracers tagged with a dye (T1824) intratracheally into canine lungs to demonstrate that virtually no tracers appear in the vascular space. Similar results were also obtained by Drinker and Hardenbergh ${ }^{5)}$, in that T1824-albumin instilled in canine lungs did not appear in the blood stream for up to 5hours. Other more recent studies ${ }^{6 \sim 11}$ have been consistent with these earlier results, in that the air-blood barrier may be relatively impermeant to protein tracers within the physiological range of lung inflation volumes.

A number of morphological studies performed by electron microscopy using protein markers (e.g., cytochrome c, horseradish peroxidase) generally support the notions that the normal air-blood barrier may be virtually impermeable to proteins. For example ${ }^{12 \sim 14)}$, protein markers were found generally not to traverse pulmonary epithelial junctions, although they freely penetrate endothelial junctions (except for catalase and ferritin, which are stopped at endothelial junctions). The epithelial junctions, how ever, were seen to allow passage of protein markers when high vascular pressures are present ${ }^{12)}$.

Contrary to the above conclusion that protein does not cross the air-blood barrier, there are numerous reports indicating that proteins are normally translocated in both directions across the air-blood barrier, although the exact transport mechanisms and pathways remain unclear. The earliest evidence in support of this alternate conclusion came from the studies of Courtice and Simmonds ${ }^{15}$, where intratracheally-administered T1824-albumin was found, proportional to the rate of ventilation, in the lymph and blood of intact rabbits. This result was essentially confirmed by Schultz et $\mathrm{al}^{16)}$ in dog lungs in situ, where instilled ${ }^{125} \mathrm{I}$-albumin was found to slowly clear from the lung air spaces into plasma. These investigators repeated the same experiments later by utilizing isolated, perfused dog lungs with ${ }^{131}$ I-albumin instilled into the air spaces, and showed that about $6 \%$ of the instilled radioactivity appeared in the vascular space at the end of a $5 \mathrm{~h}$ period. Findings similar to these have been obtained by a number of investigators, utilizing intact lungs of rats $^{17)}$, rabbits ${ }^{18 \sim 21)}$, guinea pigs $^{22)}$, $\operatorname{dogs}^{22 \sim 32)}$, and sheep $^{33 \sim 36)}$.

The pathways and transport mechanisms underlying these apparent protein flows across the air-blood barrier are not yet clear. Early on, type II alveolar epithelial cells were suggested to be the potential site of phagocytosis and or endocytosis of macromolecules ${ }^{37)}$. However, Lauweryns and Baert $^{39)}$ thought that type I pneumocytes, with the added advantage of occupying most of the alveolar surface, with the added advantage of occupying most of the alveolar surface, may also be the site of transcytosis of proteins and other macromolecules presented to the air spaces. Gil et $\mathrm{al}^{39)}$ further suggested that numerous vesicles present in the alveolar epithelial and capillary barriers may be useful to transport macromolecules by pinocytosis. The possibility of receptormediated endocytosis by the alveolar epithelium was first raised by Simionescu and Simionescu $\mathrm{u}^{40)}$, who indicated that the alveolar surface of the Type II pneumocyte is decorated by cationic ferritin at the locale of coated and uncoated pits, as well as within the vesicles. Similar findings were presented by Williams ${ }^{41,42)}$, utilizing in vivo rat lungs. She also noted cationized Maclura promifera agglutinin binds to these anionic sites located in pits and vesicles.

Bignon et $\mathrm{al}^{43.44)}$ clearly demonstrated that autologous albumin and immunoglobulin $\mathrm{G}(\mathrm{IgG})$ are present on the alveolar surfaces of the mammalian 
lung. These investigators incubated horseradish persoxidase-labeled antibodies (against albumin or IgG) with prefixed lung blocks, and demonstrated the nomal presence of IgG in alveolar epithelial cell coats, in tubular myelin, and in free granular deposits. Further noted was that autologous albumin is present on the surface of Type II pneumocytes and in vesicles in Type I pneumocytes, thereby supporting the possibility of albumin being normally translocated across the air-blood barrier. Interestingly. albumin was absent from lamellar bodies of Type II cells. These data suggest that proteins (e.g., albumin) may traverse the air-blood barrier under normal conditions, perhaps via vesicular pathways.

Apparent albumin permeabilities ranging from $5 \times$ $10^{-10} \mathrm{~cm} / \mathrm{s}$ in sheep lungs ${ }^{36)}$ to $1.9 \sim 3.4 \times 10^{-9} \mathrm{~cm} / \mathrm{s}$ in dog lungs ${ }^{29 \sim 32)}$ have been reported. The wide range of values may reflect in part the difficulties of obtaining precise of values may reflect in part the difficulties of obtaining precise measurements in intact mammalian lungs. Characterization of protein permeability properties of the allveolar epithelium under more strictly controlled experimental conditions was first attempted by Kim et $\mathrm{al}^{45}$, who utilized the simpler amphibian lung model of the alveolar epithelium. These investigators found that apparent ${ }^{14} \mathrm{C}$-albumin permeabilities across the bullfrog alveolar epithhelium are unexpectedly large compared to those of a much smaller polysawccharide, ${ }^{14} \mathrm{C}$-methylhydroxy-inulin. Furthermore, the permeability of albumin observed in the alveolar to the pleural direction is $2.3 \times 10^{-7} \mathrm{~cm} / \mathrm{s}$, about four times greater than that in the opposite direction. Inulin permeability, on the other hand, is symmetric $\left(3.1 \times 10^{-8} \mathrm{~cm} / \mathrm{s}\right)$ and much smaller than that for albumin in either direction. It was further noted that these asymmetric ${ }^{14} \mathrm{C}$-albumin fluxes were not affected by different electrical gradients (20 to $20 \mathrm{mV}$ ) imposed across the does not occur through passive, restricted diffusional routes across the alveolar epithelium. Very similar results were also found recently for excised canine bronchial epithelium by Johnson et $\mathrm{al}^{46)}$. At least some of the radiolabel is transported across the alveolar (and bronchial) epithelium on subfragments of the originally intact ${ }^{14} \mathrm{C}$-albumin. These findings on asymmetric albumin transport across the alveolar epithelium indicate that the normal air-blood barrier is capable of translocating proteins, and perhaps removing excess proteins from the alveolar fluid, lthereby helping to maintain relatively dry alveolar air spaces for efficient gas exchange.

Preliminary results reported very recently indicate that mammalian alveolar epithelium in vitro also transports proteins rapidly and asymmetrically. Kim et $\mathrm{al}^{47}$ ) showed that tight mono layer cultures of isolated rat type II pneumocytes grown on tissue culture-treated Nuclepore membranes ${ }^{48)}$ exhibit apparent ${ }^{14} \mathrm{C}$-albumin permeabilities of $2.39 \times 10^{-7}$ $\mathrm{cm} / \mathrm{s}$ in the apical to basolateral direction and $1.66 \times$ $10^{-7} \mathrm{~cm} / \mathrm{s}$ in the opposite direction. These protein permeabilities are similar to the permeability observed for the much smaller ${ }^{14} \mathrm{C}$-mannitol (about $2 \times 10^{-7}$ $\mathrm{cm} / \mathrm{s}$ ). These data taken together clearly suggest that mammalian alveolar epithelium transports proteins rapidly, favoring net removal of proteins from alveolar fluid. The underlying specific mechanisms and pathways for macromolecule translocation across the mammalian alveolar epithelium, however, largely remain to be deterimined.

It has been shown that vascularly-injected ${ }^{131} \mathrm{I}$ albumin appears in bronchoalbeolar lavage (BAL) fluid much faster in adult respiratory distress syndrome (ARDS) patients than in congestive heart failure patients ${ }^{49 \sim 51}$. These findings have usually been interpreted to suggest damage to the air-blood barrier in non-cardiogenic pulmonary edema. Bell et $\mathrm{al}^{52)}$ suggested that the air-blood barrier appears to restrict the passage of proteins in part by molecular size, based on their findings of extremely low concentrations of larger proteins (e.g., alpha ${ }_{2}$ macroglobulin) compared to smaller molecules (such as 
albumin) in the BAL fluid. Fowler et $\mathrm{al}^{53)}$ and others ${ }^{54,55)}$ reported similar findings, in that large macromolecules (e.g., alpha ${ }_{2}$ macro-globulin, immunoglubulin $\mathrm{M}$, and fibrinogen) are present in BAL fluid at extremely low concentrations. The apparent selectivity of the air-blood barrier toward proteins of different sizes seems to be disrupted by lung injury ${ }^{54)}$. Furthermore, the elevated concentrations of the larger proteins in BAL fluid following lung injury were found to persist even after the concentrations of other smaller proteins in the alveolar fluid returned to normal levels ${ }^{54}$. These results may suggest that the normal alveolar epithelium is virtually impermeable to larger protein species. while severe injury to the air-blood barrier leads to indiscriminate flow of proteins from the interstitial and vascular spaces into the air spaces. During the recovery period following ARDS, the alveolar epithelium may again become impermeable to macromolecules of the size of alpha ${ }_{2}$ macro-globulins, thereby retaining them longer in the air spaces, whereas smaller protein species may be translocated across the barrier more rapidly, perhaps via increased pinocytosis.

Another important feature of the normal BAL protein profile may be the presence of functional macromolecules such as antioxidant proteins (e.g., ceruloplasmin and transferrin) ${ }^{56,57)}$ have used the observed shifts in protein concentrations in BAL fluid following lung injury as an index of the degree of lung injury. However, in view of the discussions above, the shift in BAL fluid protein concentrations may not result from lung injruy, and may in fact be a desirable adaptive change in the rate of proteins translocation and/or selectivity by the alveolar epithelium. Accordingly, recognizing that protein transport across alveolar epithelium is probably very complex, caution should be exercised before interpreting a shift in alveolar fluid protein concentrations as an index of lung injruy.

As a final note, we might suggest that the alveolar epithelium may be a particularly advantageous route of administration of some newly-available bioengineered protein drugs (e.g., erythropoietin) which probably are not able to be taken orally. Hubbard et $\mathrm{al}^{59)}$ found that an aerosolized, synthetic analog of protease inhibitor (alpha ${ }_{1}$ antitrypsin) is cleared from the lung air spaces and found in the circulating blood in sheep. These findings, and those cited above from our own laboratory, suggest that further studies of the characteristics and regulation of macromolecule transport across alveolar epithelium may help support the use of the lung as a new site for drug delivery.

\section{ACKNOWLEDGMENTS}

This work supported in part by the National Institutes of Health (Research Grant HL38658) and New York Lung Association Lung Research Fund. The author sincerely thanks the Editor for the heart-felt invitation to write this review, when the author recently sojourned his native country after a long absence.

\section{REFERENCES}

1) Wall DA, Maack $T$ : Am J Physiol 248:C12-C20, 1985

2) Breitfeld PP, Casanova JE, Simister NE, Ross SA, McKinnon WC, Mostov KE : Am J Respir Cell Mol Biol in press, 1989

3) Fox JP : J Immunol 31:7-23, 1936

4) Drinker CK, Warren MF, MacLanhan M : J Exp Med 66:449-458, 1937

5) Drinker CK, Hardenbergh E : J Exp Med 86:7-17, 1947

6) Normand ICS, Olver RE, Reynolds EOR, Strang LB : J Physiol 219:303-330, 1971

7) Egan EA, Olver RE, Strang LB : J Physiol 244:161 $-179,1975$

8) Normand ICS, Reynolds EOR, Strang LB : J Physiol 210:151-164, 1970

9) Egan EA, Nelson RM, Beale EF : Pediatr Res 14:314 $-318,1980$

10) Egan EA : J Appl Physiol 53:121-125, 1982

11) Egan EA, Nelson RM, Olver RE : J Physiol 260:409 
$-424,1976$

12) Pietra GG, Szidon JP, Leventhal MM, Fishman AP : Science 166:1643-1646, 1968

13) Schneeberger-Keely EE, Karnovsky MJ : J Cell Biol 37:781-793, 1968

14) Schneeberger EE, Karnovsky MJ : J Cell Biol 49:319 $-334,1971$

15) Courtice FC, Simmonds WJ : J Physiol 109:103-116, 1949

16) Schultz AL, Grismer JT, Grande F : J Lab Clin Med 61:494-500, 1963

17) Gieseking R : Ergeb Allerg Pathol Anat 38:92-98, 1958

18) Gates L, Matthay MA : Am Rev Respir Dis 135: A189, 1987 (Abstract)

19) Braley JF, Dawson CA, Moore VL, Cozzini BO : J Clin Invest 61:1240-1246, 1978

20) Braley JF, Dawson CA, Moore VL : J Immunol 121: 926-929, 1978

21) Braley JF, Peterson LB, Dawson CA : J Clin Invest 63:1103-1109, 1979

22) Dominguez EAM, Liebow AA, Bensch KG : Lab Invest 16:905-911, 1967

23) Berthiaume Y, Broaddus VC, Gropper MA, Tanita T, Matthay MA : J Appl Physiol 65:585-593, 1988

24) Schultz AL, Grismer JT, Wada S, Grande F. Am J Physiol 207:1300-1304, 1964

25) Gillespie WJ, Lee G de J : Cardiovasc Res 1:42-51, 1967

26) Bensch KG, Dominguez EAM, Liebow AA : Science 157:1204-1207, 1967

27) Bensch KG, Dominguez EAM, Meyer EC, Liebow AA : Am Rev REspir Dis 101:439-448, 1970

28) Bensch KG, dominguez EAM : Yale J Biol Med 43: 236-241, 1971

29) Goetzman BW, Visscher MB : J Physiol 204:236 $-241,1971$

30) Meyer EC, Dominguez EAM, Bensch KG : Lab Invest 20:1-8, 1969

31) Goodale RL, Goetzman BW, Visscher MB : Am J Physiol 219:1226-1230, 1978

32) Gee MH, Staub NC: J Appl Physiol 42:144-149, 1977

33) Matthay MA, Landolt CC, Staub NC: J Appl Physiol 53:96-104, 1982

34) Matthay MA, Berthiaume Y, Staub NC: J Appl Physiol 59:928-934, 1985

35) Berthiaume Y, Staub NC, Matthay MA : J Clin Invest 79:335-343, 1987
36) Gorin AB, Stewart PA : J Appl Physiol 47:1315 $-1324,1979$

37) Corrin B : Thorax 24:110-114, 1969

38) Lauweryns JM, Baert JH : Am Rev Respir Dis 115: 625-683, 1977

39) Lauweryns JM, Baert JH : Am Rev Respir Dis 115: 625-683, 1977

40) Simionecu D, Simionescu UM : Microvasc Res 25:85 $-100,1983$

41) Williams MC: Proc Natl Acad Sci USA 81:6054 $-6058,1984$

42) Williams MC : Proc Natl Acad Sci USA 81:6383 $-6387,1984$

43) Bignon J, Chahinian P, Feldmann G, Sapin C : J Cell Biol 65:503-509, 1975

44) Bignon J, Jaurand MC, Pinchon MC, Sapin C, Warnet JM : Am Rev Respir Dis 113:109-120, 1976

45) Kim KJ, LeBon TR, Shinbane JS, Crandall ED. J Appl Physiol 59:1290-1297, 1985

46) Johnson LG, Cheng PW, Boucher RC : J Appl Physiol 66:2772-2777, 1986

47) Kim KJ, Cheek JM, Crandall ED : Am Rev Respir Dis 139:A477, 1989 (abstract)

48) Cheek JM, Kim KJ, Crandall ED : Am J Physiol 256: C688-C693, 1989

49) Anderson RP, Holliday RL, Driedger AA, Lefcoe M. Reid B, Sibbald WJ : Am Rev Respir Dis 119:869 -877, 1979

50) Sprung CL, Rackow EC, Fein IA, Jacob AI, Isikoff SK : Am Rev Respir Dis 124:718-722

51) Gelb AF, Klein E : Am Rev Respir Dis 114:831-835, 1976

52) Bell DY, Haseman JA, Spock A, McLennan G, Hook GER : Am Rev Respir Dis 124:72-79, 1981

53) Fowler AA, Walchak $S$, Ciclas PC, Henson PH, Hyers TM : Chest 81:50S-51S, 1981

54) Holter JF, Weiland JE, Pacht ER, Gadek JE, Davis WB : J Clin Invest 78:1513-1522, 1986

55) Merrill WW, Naegel GP, Olchowski JJ, Reynolds HY : Am REv Respir Dis 131:584-587, 1985

56) Galdston M, Levytska V, Schwartz MS, Magnusson B : Am Rev Respir Dis 129:258-263, 1984

57) Pacht ER, Davis WB : J Appl Physiol 64:2092-2099, 1988

58) Lykens MG, Davis WB, Pacht ER : Am Rev Respir Dis 139:A752, 1989 (Abstract)

59) Hubbard RC, Casolaro MA, Mitchell M, Sellers SE, Arabia F, Matthay MA, Crystal RG : Proc Natl Acad Sci USA 86:680-684, 1989 